\author{
lu. Chupryna \\ Doctor of Economics, Associate Professor, Professor of Management \\ in Construction \\ chupryna_yura@ukr.net, orcid.org/0000-0002-4934-2058 \\ Kyiv National University of Construction and Architecture, Ukraine
}

\section{Pokolenko}

Doctor of Technical Sciences, Professor of Management in Construction pokolenkoo@ukr.net,orcid.org/0000-0003-1750-5964

Kyiv National University of Construction and Architecture, Ukraine

\section{Horbach}

Candidate of technical sciences, Associate Professor of Management in Construction maxoha@ukr.net,orcid.org/0000-0002-3784-0404

Kyiv National University of Construction and Architecture, Ukraine

\section{Bolebrukh}

Graduate student of the Department of Management in Construction bolebrukh.oleg@gmail.com,orcid.org/0000-0002-6205-1124

Kyiv National University of Construction and Architecture, Ukraine

\section{Hrabchak}

Graduate student of the Department of Management in Construction pto563@gmail.com, orcid.org/0000-0001-8623-6118

Kyiv National University of Construction and Architecture, Ukraine

\title{
MODEL OF STRATEGIC ANALYSIS OF FORMATION AND ADMINISTRATION OF INVESTMENT ACTIVITY OF STOCKHOLDER CONSTRUCTION COMPANY
}

\begin{abstract}
The article analyzes the market position of construction companies and builds a justification for updated methodological and analytical tools for evaluating, selecting, and building a productive system of portfolio administration of housing projects, which are implemented in a single operating system of the development company. The problems of investment activity of stakeholder construction companies, which have been constantly carried out in many countries by prominent foreign and domestic scientists, have been studied. Several variants of circumstances that shape the external and internal environment of the developer are analyzed, which must be taken into account when determining the strengths and weaknesses of the enterprise, its capabilities and threats, which provides a general picture of the internal situation and is important for developing optimal strategy for the enterprise.

The operating system is determined by the introduction of fundamentally new updated scientific and applied tools designed to provide the development company with a clear formalization and proper analytical support of the processes of formation, analysis, and productive subsequent administration: the leading innovation of the tools introduced commercial housing construction, which are implemented in a complex economic and managerial format production-technological, resource-logistical and administrative management of the content of business processes of project cycles as part of the portfolio of housing construction projects of the developer.
\end{abstract}


Keywords: SPACE analysis, SWOT-analysis of the developer company, portfolio of housing construction projects of the developer company (PPBZh-KD), asset management company (AMC), methodological and applied tools for the formation and administration of PPBZh-KD.

\section{Introduction}

The difficult situation and significant structural problems of the domestic economy give the issue of intensification of investment activities of construction companies the status of priority. Implementation of successful investment projects in construction acquires special macroeconomic significance in such conditions, as it allows not only to increase construction production, employment and tax payments to state and local budgets, but also to increase the technical and technological level of other sectors of the economy and public life.

The life cycle of each investment project begins with the stages of planning and preliminary analysis, the quality of which largely depends on the success of the project, if the latter is accepted for implementation. Accordingly, there is a need for a quality methodology for determining the economic efficiency of investment projects, the development and implementation of which is an important task of modern economics.

\section{Literature Review}

Research on the problem of investment activities of construction stakeholder companies has been conducted in many countries. The theoretical achievements are the scientific works of economists of different times: I. Fisher, A. Smith, J. Keynes and others. Today Ukraine's economy needs a significant infusion of money in the form of investment income. The works of domestic scientists, namely: V.Ya. Ambrosova, S.I Demyanenko, Yu.O. Lupenko, SA Ushatsky [9], O.V Oliynyk, Yurchyshyn and others.

Problems of investment activity and investment activity are revealed in the works of I. Blank, [2], A. Galchinsky, H. Tanaka [2], J. Petrovich, T. Protsyk, V. Pokolenko, [8], G. Ryzhakov, [1 ], P. Kulikov, N. Bushuyeva [5], Y. Tesla [3], Some aspects of investment support were studied by A. Butenko, D. Vankovich, S. Zakharin, O. Yemelyanov, H. Chupryna [7], Yu. Captain, N. Yegorchenkova [6], T. Tovt, J. Shevtsov, O. Yastremska. The analysis of existing research provides an opportunity to assert the relevance of this problem, and therefore requires further consideration.

\section{Aims}

The purpose of this article is the methods of enterprise analysis and improvement of the process of formation, administration of the business environment of construction stakeholder enterprises based on innovative tools. Comprehensive use of SPACE analysis and SWOT analysis allows not only to determine the market position of construction companies in a competitive environment and assess its competitive advantages, strengths and weaknesses, opportunities and threats, but also to identify signals of crisis in the operation and development of construction companies. Initially, on the basis of SPACE-analysis, the competitive position of construction companies is determined.

The essence of SPACE-analysis is that SPACE-analysis (Strategic Position and Action Evaluation) provides four evaluation coordinates: FS, CA, ES, IS, where FS determines the financial condition of construction companies, CA - its competitive advantages, ES characterizes the degree of external stability environment and IS determines the attractiveness (strength) of the financial market. It should be noted that this method is a tool for strategic analysis and planning which allows you to assess the overall attractiveness of the activity, the ability to compete in the market and develop an effective crisis management strategy that would provide recommendations to prevent and overcome the crisis [1-2]. 
Based on this, the author presents the factors that determine the strategic position of construction companies and their rating system.

The next stage identifies the strengths and weaknesses of construction companies, their opportunities and threats. To conduct a SWOT-analysis, first of all, it is necessary to determine the main factors of the external and internal environment that signal possible changes in the existing state of the construction company.

It is almost impossible to establish all possible variants of signals due to the variety of circumstances that shape the state of the external and internal environment, it is impossible to consider. However, the most significant sources and nature of such signals can be identified. Factors that must be considered when determining the strengths and weaknesses of the enterprise, its capabilities and threats are determined as follows (Table 1) [3].

Table 1. Matrix of SWOT-analysis of researched enterprises

\begin{tabular}{|c|c|}
\hline Potential internal strengths & Potential internal weaknesses \\
\hline Full competence in key areas & Lack of a clear strategic direction of development \\
\hline Adequate financial resources & Obsolete fixed assets \\
\hline Good impression of the company from buyers & Insufficient profitability \\
\hline Recognized market leader & Lack of competent and far-sighted management \\
\hline Well-thought-out strategies in functional areas & Lack of some experience and competence \\
\hline Possibilities of using scale effect & Weak implementation of the strategy \\
\hline Protection against competitive pressure & Many internal operational problems \\
\hline Own technology & Lag of research and development \\
\hline Cost advantage & The range is too narrow \\
\hline Better advertising & Low market reputation \\
\hline Product improvement & Weak distribution network \\
\hline Good management & Insufficient experience in marketing \\
\hline Great production capacity & Higher unit costs than competitors \\
\hline Excellent technological skills & Other \\
\hline \multicolumn{2}{|l|}{ Other } \\
\hline Potential external opportunities & Potential external threats \\
\hline $\begin{array}{l}\text { Ability to serve additional groups of consumers } \\
\text { or penetrate new markets or market segments }\end{array}$ & $\begin{array}{l}\text { Entering the market of foreign competitors with } \\
\text { lower costs }\end{array}$ \\
\hline $\begin{array}{l}\text { Ability to expand the product range to meet } \\
\text { customer demand in a wider range }\end{array}$ & Growth in sales of substitute products \\
\hline $\begin{array}{l}\text { Ability to transfer experience and technological } \\
\text { know-how to a new product or business }\end{array}$ & Slowing market growth \\
\hline Back and forth integration & $\begin{array}{l}\text { Adverse change in foreign exchange rates and } \\
\text { foreign government policies in foreign trade }\end{array}$ \\
\hline $\begin{array}{l}\text { Overcoming trade barriers in attractive foreign } \\
\text { markets }\end{array}$ & Expensive legal requirements \\
\hline Weakening the position of competing firms & $\begin{array}{l}\text { High dependence on declining demand and the } \\
\text { stage of the business development life cycle }\end{array}$ \\
\hline $\begin{array}{l}\text { The possibility of rapid development due to the } \\
\text { sharp increase in market demand }\end{array}$ & $\begin{array}{l}\text { The growth of market power of consumers or } \\
\text { suppliers }\end{array}$ \\
\hline The emergence of new technologies & Changing needs and tastes of buyers \\
\hline Other & Adverse demographic change, more \\
\hline
\end{tabular}


Thus, SWOT-analysis is a general picture of the internal situation and is of great importance for the development of optimal strategy. The strengths of the company form the foundation for developing a strategy for its development. No less important is the procedure for identifying the weaknesses of the enterprise - these are areas of special attention. The strengths of the enterprise are its features that allow to determine and form competitive advantages. Weaknesses of the enterprise are those indicators that determine its competitive vulnerability [3-4].

The process of transformation of Ukraine's economy over the past two decades has exacerbated the problem of ensuring the competitive advantages of construction companies. This circumstance is since the process of attracting investment resources necessary for the innovative development of construction companies which was not provided. Obviously, compared to enterprises in other industries of the country, construction companies are less attractive to investors for a number of reasons:

- for a construction company is characterized by larger capital investments with a longer payback period;

- a feature of the organization of a construction company is a high level of knowledge-intensive products and long cycles of its production and sale which significantly slows down the turnover of current assets.

Analysis of the factors that determine changes in the external environment showed that the external environment affects the activities of construction companies. This suggests the need for constant monitoring of changes in the external environment, determining its impact on the financial condition of enterprises and timely adjustment of development strategies. Particular attention should be paid to factors such as demand, government activities, the financial market and the foreign economic environment. Changes in these parameters should be considered when developing effective crisis strategies [5].

Positive or negative changes in the above environmental factors cause additional opportunities or threats to construction companies. Rational use of opportunities can significantly improve the financial condition and strengthen the competitive position of domestic construction companies in the market while ignoring the threats can lead to a crisis in the enterprise. Based on the conducted research the following stages of monitoring of external and internal environment of the construction enterprises are offered (fig. 1). 


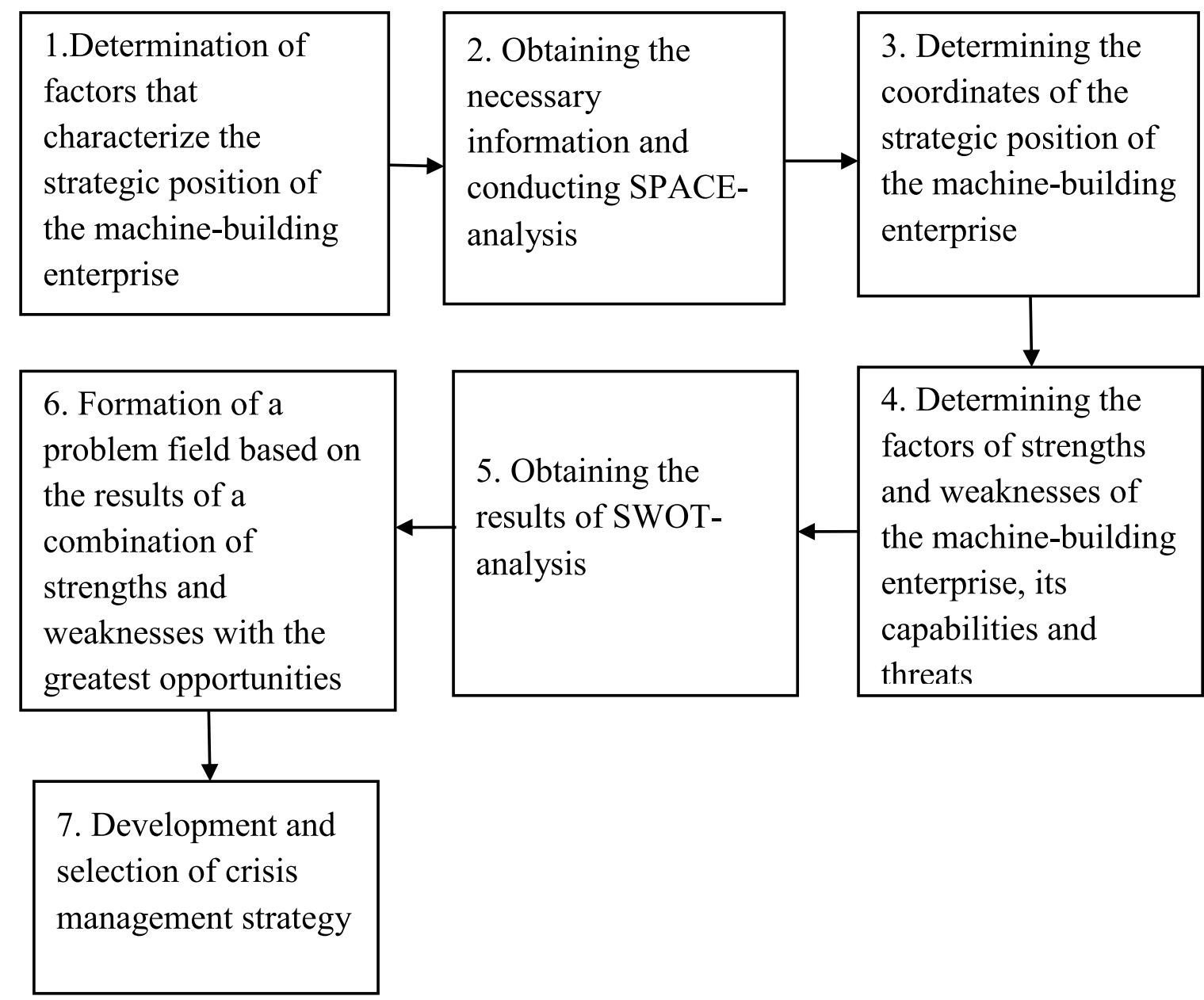

Fig. 1. Stages of monitoring the external and internal environment of construction companies

It should be noted that the monitoring of the internal and external environment allows to diagnose early signals of the beginning of the crisis in the processes of functioning and development of construction enterprises. Therefore, we can conclude that the integrated use of SPACE-analysis and SWOT-analysis for monitoring allows to determine the market position of construction companies in a competitive environment and assess its competitive advantages, strengths and weaknesses, opportunities and threats.

Monitoring the key factors of SWOT-analysis allows to develop effective anti-crisis management strategies that support the constant readiness of construction companies for the crisis and adjust them to changes in the external and internal environment. Thus, an improved approach to monitoring the internal and external environment of enterprises on the basis of integrated use of SPACE-analysis and SWOT-analysis allows to identify the manifestations of crisis situations and adjust development strategies.

The cost of the construction object is directly related to the applied technologies of construction organization and technical solutions. As mentioned earlier, innovative technologies can reduce the cost of production and, consequently, the final cost of construction products. The possibility of implementing and applying innovations in the construction industry depends on the existing external and internal environment. In the first section, the author proposes a classification of factors influencing the formation of the innovative potential of the construction company [5-6]. 
Thus, indicators of external influence affecting the innovative business entity of the construction industry are: [4]

1. competition;

2. demand for finished products in the industry;

3. the average level of capacity utilization in the industry;

4. level of state support;

5. the level of socio-economic development of the region;

6. the economic situation in general in the construction industry;

7. level of entrepreneurial confidence in the construction industry.

In turn, the indicators of the internal environment of the enterprise, which affects its innovation potential, include:

1) social:

- the level of involvement of employees of the organization;

- timeliness of payment of wages;

2) organizational and managerial:

- the share of employees involved in innovative projects from the total number of management staff;

- frequency of marketing research;

3) production and economic:

- the share of intangible assets in the total cost of fixed capital;

- participation in contract bidding;

- execution of the order on commissioning of objects;

- the volume of execution of the construction and installation work under the agreement (contract);

- Labor productivity per employee, thousand UAH/day;

- level of profitability;

- financial stability;

- customer satisfaction;

- deviations in terms of construction duration;

- uniformity of construction;

- application of effective methods of organization and technology of construction production;

- provision of labor resources;

- provision of building materials and structures;

- level of specialization of the construction organization.

4) technological:

- level of automation of construction processes;

- quality of construction works;

- compliance with the rules of TV and labor protection;

- quality of design and estimate documentation;

- share of highly qualified personnel.

One of the main purposes of such gradation is to determine the main indicators that affect the innovation potential of the enterprise with the subsequent development of guidelines for determining its rating. It is assumed that the value of indicators that characterize the innovative potential of enterprises that reflect the external environment is determined on the basis of statistical data provided by the State Statistics Service of Ukraine. 
Indicators that allow you to analyze the internal environment of the business entity are determined based on retrospective financial statements, statistics of the enterprise by conducting a survey as well as marketing research. The above indicators of the external environment allow us to predict trends in the construction market, to determine the level of demand for finished products and the state's focus on innovative development. Forecasting demand, competition and investment support of the state in the construction industry are of great importance due to the specifics of the production of finished products.

In a market economy is characterized by trends of accelerating development, compaction of time, increasing the number and variety of changes that characterize the conditions of the construction company. Management must keep up with the changes that are taking place in reality. And the factor of such correspondence of management to the changes which occur in an economic life, a science and technics, is innovative potential of management which is formed in work with the personnel, preparation of managers, the organization of management focused on dynamics. [6]

The defining scientific and applied prerequisite of the study is the urgent need to fundamentally update the methodological approach to the content and operational technology of the portfolio of housing construction projects of the developer (PPBZh-KD) - in the direction of introduction and justification of modernized tools for forming PPBZh-KD as a specific business -developer because the specifics of commercial housing projects and features of mandatory regulation of their cycle by the asset management company - makes it impossible to use traditional ideas, approaches and applied tools to form the economic portfolio of the developer [7].

And it is the innovative potential of the enterprise that has built the tools as a holistic methodological and analytical technology, the components of which are implemented by a separate stage of formation of KSB (construction stakeholder companies) (Table 2). The introduced technology is a component of the operating system (OS) of the developer as a result provides synergy of the results of the specified PPBZH-KD (working as a leading stakeholder in several housing projects) (in parallel or sequentially) as strategic business units [7].

Table 2. Content-process scheme of tools for the formation and administration of a portfolio of construction projects.

\begin{tabular}{|l|l|l|l|}
\hline No & $\begin{array}{l}\text { Name } \\
\text { of the stage }\end{array}$ & $\begin{array}{l}\text { The content and regulations of the stage } \\
\text { structured according to its business elements }\end{array}$ \\
\hline 1. & $\begin{array}{l}\text { Formation } \\
\text { of applied } \\
\text { prerequisites for } \\
\text { the selection } \\
\text { of proposals } \\
\text { for the } \\
\text { administration } \\
\text { of commercial } \\
\text { housing projects } \\
\text { as SGO in } \\
\text { the portfolio } \\
\text { of developer } \\
\text { projects }\end{array}$ & 1.1. & $\begin{array}{l}\text { Initial current elaboration of the state and dynamics of environmental factors } \\
\text { in relation to construction development for housing construction projects, } \\
\text { including indirect impact of commercial housing market trends and possible } \\
\text { effects of changes in the regulatory and regulatory activities of the organization } \\
\text { of administration, financing, preparation, construction and commissioning of the } \\
\text { product of projects - housing construction projects. }\end{array}$ \\
\cline { 2 - 4 } & 1.2. & $\begin{array}{l}\text { Initial evaluation of potential customers' proposals for concluding contracts with } \\
\text { this CD for preparation and administration by the functional-operational cycle } \\
\text { (FOC) of the project(s) in commercial housing construction - on the content of } \\
\text { tasks and duration of FOC, distribution of responsibilities and economic results for } \\
\text { intermediate and finished product. }\end{array}$ \\
\cline { 2 - 3 } & 1.3. & $\begin{array}{l}\text { The initial analytical evaluation of the projects presented according to item 1.2, } \\
\text { according to the system of analytical indicators which is formalized for the needs } \\
\text { of CD evaluates economic, functional-technical, administrative-personnel and } \\
\text { image characteristics of CD participation in each of the projects. }\end{array}$ \\
\hline
\end{tabular}




\begin{tabular}{|c|c|c|c|}
\hline \multirow[t]{6}{*}{2.} & \multirow{6}{*}{$\begin{array}{l}\text { Preparation } \\
\text { and selection } \\
\text { of alternatives } \\
\text { PPBZh_KDu } \\
\text { format of a } \\
\text { single visual- } \\
\text { analytical model }\end{array}$} & 2.1. & $\begin{array}{l}\text { Clarification (including with the involvement of independent experts) of the } \\
\text { characteristics of projects, their coordination with potential customers. }\end{array}$ \\
\hline & & 2.2 . & $\begin{array}{l}\text { Making a final decision on the participation of KD as a leading stakeholder in } \\
\text { housing construction projects as a SGO in the PPBZ. }\end{array}$ \\
\hline & & 2.3. & $\begin{array}{l}\text { Formalized analytical presentation of CD operating system as a system of } \\
\text { interaction of subsystems of CD operating system (1-subsystem of development } \\
\text { strategy and business planning; } 2 \text { - subsystem of financial and resource-logistical } \\
\text { support; } 3 \text { - subsystem of regulation) with local subsystems of administration } \\
\text { of housing projects as strategic and the administrative environment for the } \\
\text { implementation of their projects, which is regulated by the AMC. }\end{array}$ \\
\hline & & 2.4 . & $\begin{array}{l}\text { Development of options for synergistic ordering of content cycles for individual } \\
\text { projects. }\end{array}$ \\
\hline & & 2.5 . & Visual-graphic representation of variants of integral PPBZh-KD. \\
\hline & & 2.6. & $\begin{array}{l}\text { Evaluation of the options of integral PPBZh-KD according to the innovative } \\
\text { system of criteria taking into account the evaluation of the reactions of the } \\
\text { operating system KD as a project-adapted synergistic economic and administrative } \\
\text { complex of the CSO. (description below). }\end{array}$ \\
\hline \multirow[t]{4}{*}{3.} & \multirow{4}{*}{$\begin{array}{l}\text { Setting up } \\
\text { the operating } \\
\text { system and } \\
\text { organizational } \\
\text { structure of } \\
\text { the developer } \\
\text { company for } \\
\text { the content of } \\
\text { the PPBZ-KD } \\
\text { implementation } \\
\text { cycles }\end{array}$} & 3.1. & $\begin{array}{l}\text { Coordination of the composition of works on the administration of projects on the } \\
\text { side of the CD with other institutional participants - AMC, the customer and its } \\
\text { co-investors. }\end{array}$ \\
\hline & & 3.2. & $\begin{array}{l}\text { Initial formation of the content of agreements between the company developer, } \\
\text { institutional participants and stakeholders (executors) of the project. }\end{array}$ \\
\hline & & 3.3. & $\begin{array}{l}\text { Final coordination of agreements (contracts) that reflect the content and essence } \\
\text { of economic-administrative and functional interaction of CD with project } \\
\text { participants which are included in PPBZ-CD. }\end{array}$ \\
\hline & & 3.4 . & $\begin{array}{l}\text { Implementation of the necessary economic, technological, information-analytical } \\
\text { and organizational-administrative measures to adapt the existing operating } \\
\text { system and organizational structure of the company to the process of actual } \\
\text { implementation of projects (elements-SGO). }\end{array}$ \\
\hline \multirow[t]{3}{*}{4.} & \multirow{3}{*}{$\begin{array}{l}\text { Management of } \\
\text { FOC projects as } \\
\text { a part of PPBZh- } \\
\text { KD }\end{array}$} & 4.1. & $\begin{array}{l}\text { Completion of elaboration of design and estimate, organizational, technological, } \\
\text { budgetary and administrative documentation for projects within the PPBZH-KD. }\end{array}$ \\
\hline & & 4.2. & $\begin{array}{l}\text { Implementation of projects. Operational adjustment of the functional and } \\
\text { operational cycles of projects. Interim budgetary-economic, technological and } \\
\text { administrative control over the implementation of WTO projects. }\end{array}$ \\
\hline & & 4.3. & $\begin{array}{l}\text { Assessment of the impact of the results of the cycle of individual projects and } \\
\text { the portfolio as a whole on the financial results, the overall performance of the } \\
\text { operating system CD and the growth of its qualifying assets. }\end{array}$ \\
\hline
\end{tabular}

During the formation of the toolkit, a number of scientific and methodological innovations were implemented in relation to the economy and operational management of the developer as a stakeholder of the project portfolio (investment and property complex) $[1,7,8]$.

1. This toolkit on the content and direction of the stages of formalized development, selection of housing construction projects in the portfolio of the developer and their subsequent productive implementation successfully combines: effective development platforms with modern concepts of construction management and budgeting and productive information-analytical basis construction.

2. The tools modernize the approach in the evaluation of construction projects as elements of the CSR as part of the business portfolio (project portfolio) of the developer. For the needs of the initial local assessment of the cycle of housing construction projects in terms of feasibility (from the standpoint of CD) their inclusion in the PPBZH-CD used a modernized system of $\mathbf{R}$-indicators (1)-(4), which assess the competitiveness of the project as an object of profitable investment. commercial real estate, as well as the leading determinants of the stability of the real estate customer and the investment object; 
These indicators are presented in the universal dimension (as a result of correlation of local evaluations of projects $\mathbf{Z}_{\mathbf{1}}(\mathbf{m})$... $\mathbf{Z}_{\mathbf{6}}(\mathbf{m})$ on these indicators with their statistically or imperatively determined exemplary analogues $\mathbf{Z}^{\text {et }}(\mathbf{m}) \ldots . . \mathbf{Z}^{\text {et }}(\mathbf{m})$ for region and industry) and further - combined into an "integrated indicator for assessing the economic reliability of the UPS cycle":

$$
\begin{aligned}
& \mathrm{R}_{\text {int }}(\mathrm{m})=\Sigma_{\mathrm{g}} \psi(\mathrm{g}) * \mathrm{Rg} ; \mathrm{Rg}=\mathrm{Z}_{\mathrm{g}}(\mathrm{m}) / \mathrm{Z}_{\mathrm{g}}^{\mathrm{et}}(\mathrm{m}) ; \mathrm{Rg} \leq 1 ; \mathrm{g}=1-6 ;
\end{aligned}
$$

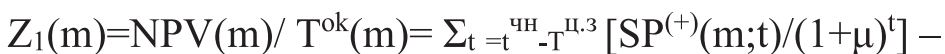

$$
\begin{aligned}
& \Sigma_{\mathrm{t}}=\mathrm{t}_{-\mathrm{t}}^{0}{ }^{3 . \mathrm{i}}\left\{\left[\mathrm{Bd}(\mathrm{m}, \mathrm{t}) /(1+\mu)^{\mathrm{t}}\right]\right\} / \mathrm{T}^{\mathrm{ok}}(\mathrm{m}) ; \mathrm{t}^{0}<\mathrm{t}^{3 \mathrm{i}}<\mathrm{t}^{\mathrm{4H}}<\mathrm{T}^{\mathrm{ok}}<\mathrm{T}^{\mathrm{MP}}<\mathrm{T}^{\text {ц3 }} \\
& \mathrm{Z}_{2}(\mathrm{~m})=\operatorname{IDp}(\mathrm{m}) * \operatorname{IRR}(\mathrm{m}) \\
& \mathrm{Z}_{3}(\mathrm{~m})=\Sigma_{\mathrm{t}} \mathrm{QW}^{\mathrm{ag}}(\mathrm{m}) / \mathrm{Tj}=\Sigma_{\mathrm{t}}\left[\mathrm{dReg}^{\mathrm{NPV}}{ }_{\mathrm{j}}(\mathrm{t}) / \mathrm{dt}\right] / \mathrm{Tj} \\
& \mathrm{Z}_{4}(\mathrm{~m})=10000 / \sigma^{2}\{\mathrm{NPV}(\mathrm{m})\} \\
& \mathrm{Z}_{5}(\mathrm{~m})=\mathrm{Y}_{6}^{\text {inv,act }}=10000 / \sigma^{2}\left\{\mathrm{SP}^{(+)}(\mathrm{m}\}\right. \\
& \mathrm{Z}_{6}(\mathrm{~m})=\Sigma_{\mathrm{k}=1-3}\left\{\mathrm{CHOK}_{\mathrm{k}} / \mathrm{B}^{\text {дж}} \mathrm{k}\right\}
\end{aligned}
$$

where, $\mathbf{g}$ - is the ordinal number of the indicator;

$\mathbf{m}$ - serial number of the project in the primary general list of projects subject to initial assessment of the feasibility of their inclusion in the PPBZH-KD;

$\mathbf{Z}_{1}(\mathbf{m})$ - the first indicator calculated as weighted for the payback period of the project net consolidated (discounted) income of the project, UAH million/year; the growth of the indicator maximizes the volume and intensity of the project profitability during all phases of the FOC of the project;

$\mathbf{Z}_{\mathbf{2}}(\mathbf{m})$ - the second indicator calculated by the product of the project profitability index and the internal rate of return of the project (in units); the growth of the indicator ensures the predominant growth of the project's income assets over the investor's liabilities, and, at the same time, minimizes the types of investment risk covered by the internal profitability of the project, first of all, inflation, speculative and other sectoral and project risks;

$\mathbf{Z}_{\mathbf{3}}(\mathbf{m})$ - is an indicator of the current rate of growth of the project cost determined by the ratio of the sum of the ordinates of the current rate of growth of project assets to the total duration of the project cycle. Maximization of this indicator provides growth of positive (income) intensity of FOC-project and minimization of its negative (expense) part, promotes selection of projects with more rational structure of assets and better correlation of duration of investment and operational phases of a cycle;

$\mathbf{Z}_{4}(\mathbf{m})$ - is the fourth criterion which minimizes the NPV variation, which is estimated by the standard deviation; thus, the methodical and applied continuity of stages of selection of projects and growth of reliability of the received forecast design characteristics of PPBZh-KD as a whole is provided;

$\mathbf{Z}_{5}(\mathbf{m})$ - the fifth indicator - provides the maximum reliability of investment pre-selection of projects in the composition of PPBZH-KD by minimizing the standard deviation of the most difficult to predict project variable - net revenue flow $\mathbf{S P}^{(+)}(\mathbf{m})$; 
$\mathbf{Z}_{6}(\mathbf{m})$ - the sixth indicator which provides the developer with a picture of the liquidity of assets and solvency of the customer company m-volume anti-bankruptcy project for the customer company; calculated as the average for the customer for the last 3 years, the share of net working capital of organizations in the total volume of its sources;

$\mathbf{R g}(\mathbf{m})$ - relative project estimates by indicators, determined by the ratio of real values of indicators $\mathrm{Zg}(\mathrm{m})$ to their sample (reference) values Zetg $(\mathrm{m})$, which are determined by the developer based on the results of market evaluation of investments in commercial housing;

$\mathbf{R}_{\text {int }}(\mathbf{m})$ - an integrated indicator for assessing the economic reliability of the housing project cycle;

$\boldsymbol{\psi}(\mathrm{g})$ - coefficients of specific weight of values in the composition of the integrated indicator $\mathbf{R}_{\text {int }}(\mathbf{m})$; are determined by the ranks of indicators established by expert heuristics;

$\mathbf{t}$ - number of the current project cycle implementation period (month); Tok (m) payback period of the project;

$\mathbf{T}^{\text {ed }}$ - the estimated duration of the life cycle;

$t^{\text {tb }}$ - time of the beginning of net receipts (net cash flow) on the project with reference at the moment of the beginning of a cycle (t0);

$\mathbf{t}^{\mathrm{t}}$ - time of completion of investment, counting at the beginning of the cycle $(\mathrm{t} 0)$;

$\mathbf{T}^{\text {ts }}$ - the term of the settlement project capacity (according to the directive level of achieving a certain volume of housing sales);

NPV(m) - net present value (net discounted income) of the project determined by the estimated duration of the cycle $\mathrm{Tr}, \mathrm{c}$;

$\mathbf{B d}(\mathbf{m}, \mathbf{t})$ - the amount of investment costs determined for a particular t-current period (according to the investment budget, consolidated estimate and resource-calendar plan of investment development);

$\mathbf{B d}(\mathbf{m}, \mathbf{t}) /(\mathbf{1}+\boldsymbol{\mu})^{\mathbf{t}}$ is similar to $\mathbf{B d}(\mathbf{m}, \mathbf{t})$, but discounted at the beginning of the $\mathbf{m}$-project cycle;

$\mathbf{S P} \mathbf{P}^{(+)}(\mathbf{m} ; \mathbf{t})$ - the amount of net revenue flow for a particular $\mathrm{t}$-current period (during the operational phase, which for projects of this type lasts from the beginning of sales to their completion, and may occur in parallel with the investment phase of the cycle), projects of this content are determined by the current difference: net revenue from housing sales and all operating costs of the operational phase (including both sales service costs and costs of administration of this flow by the CD and $A M C)$;

$\mathbf{S P} \mathbf{P}^{(+)}(\mathbf{m} ; \mathbf{t}) /(\mathbf{1}+\boldsymbol{\mu})^{\mathbf{t}}$ is similar to $\mathbf{S} \mathbf{P}^{(+)}(\mathbf{m} ; \mathbf{t})$, but discounted at the beginning of the $\mathbf{m}$-th project cycle;

$\boldsymbol{\Sigma}_{\mathbf{t}=t-\mathrm{t}}^{\mathbf{0}}$ 3.i $\left\{\left[\mathbf{B d}(\mathbf{m}, \mathbf{t}) /(\mathbf{1}+\boldsymbol{\mu})^{t}\right]\right.$ - the amount of discounted at the current moment of the cycle volume of investments for the entire duration of sales

$\Sigma_{t=t}^{\text {чн }}{ }_{\text {-т. }}^{\text {п.3 }}\left[\mathbf{S P}^{(+)}(\mathbf{m} ; \mathbf{t}) /(\mathbf{1}+\boldsymbol{\mu})^{\mathrm{t}}\right]$ - the sum of the discounted volumes of the net flow of receipts calculated at the current moment of the cycle, $\mathrm{mln}$.

$\mathbf{I D p}(\mathbf{m})$ is the profitability index of the project, determined by the ratio $\boldsymbol{\Sigma}_{\mathbf{t}=\mathbf{t}-\mathbf{t}}^{\mathbf{0}} \underset{\text { s.i }}{\mathbf{f}}[\mathbf{B d}(\mathbf{m}, \mathbf{t}) /$

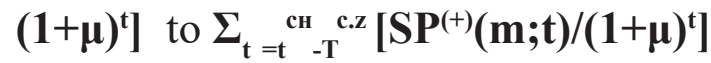

$\operatorname{Reg}^{\mathrm{NPV}}(\mathbf{t})$ - regression function (polynomial of the 5 th degree), which simulates the distribution of net consolidated NPV income for this $\mathbf{m}$-th project;

$\mathbf{d R e g}^{\mathrm{NPV}}(\mathbf{t}) / \mathbf{d t}$ - the first derivative of the function RegNPV $(\mathrm{t})$ at time $t$;

$\mathbf{Q} \mathbf{W}^{\mathrm{ag}}(\mathbf{m})$ - the current growth rate of the cost of the $\mathbf{m}$-th project;

At the next stages, in accordance with the above operational technology, the formation, evaluation of options PPBZH-KD and their implementation. The selection of the final variant is carried out in such a way as to give a maximum to the integral target criterion $\mathbf{\partial}(\mathbf{h})$, which 
- through the coefficients of proportionality and comparative weight $\boldsymbol{\rho}(\mathbf{h})$ - combines inter-

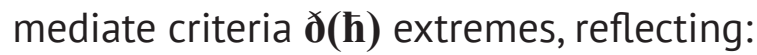

$$
\max \longleftarrow ð(\hbar)=\rho(\hbar) * ð(\hbar)
$$

ð (1) - financial result from the implementation of its PPBZH-KD, weighted for the entire period of its implementation (million UAH / year)

ठ (2) - the share of the developer's own sources in the total budget of PPBZH-KD, (share of units);

ð (3) - indicator of profitability of own sources, (\%, weighted on average for all portfolio projects)

ठ (4) - the level of current liquidity of the developer's assets (the share of units weighted on average for all projects for the entire period of implementation of the portfolio);

ठ (5) - increase in the volume of all assets of the developer (UAH million)

Giving maximum to the integrated criterion will provide the developer with a convenient, formalized and reliable opportunity to choose the alternative PPBZH-KD, which will provide the developer with the maximum financial result (taking into account the duration of the entire portfolio cycle) and provide the highest growth. investment and property complex of housing construction objects [7-9].

\section{Conclusion}

The model of strategic analysis and formation of the investment business environment of this complex were aimed at ensuring productive and formalized process management: analysis of strengths and weaknesses of construction companies, selection of projects in the developer's portfolio, their preparation, sales service, construction and implementation of completed projects. housing construction projects. A fragment of the system algorithm of OS operation for a developer company operating in the market of commercial housing construction is presented. The tasks of investment projects include both the assessment and justification of the composition of PPB$\mathrm{ZH}-\mathrm{KD}$, and the adaptation (modernization and engineering) of the organizational structure of the development company to the content of the tasks of PPBZh-KD administration.

Substantive, methodical and calculation-analytical suitability of the tool provides analytical support for the development of the construction project of housing construction as a separate strategic economic unit within the PPBZH-KD throughout the operational cycle - from approval of the development agreement to the end of this agreement. The customer, subcontractors, AMC and other stakeholders and achieving the target capacity of the project as a commercial housing object.

\section{References}

1. Ryzhakova, G. (2013). Alternative analytical tools for ensuring the economic security of public investment in construction projects. Management of complex systems development. no. 16, 203 - 208.

2. Tanaka, H. (2006). Increasing the return on investment in construction and project management: the experience and prospects of Japan. Project and program management, 1 (5), 24-40.

3. Tesla, Yu. Gots, V., \& Gots, H. Sources of formation of the information environment of the development company. Access mode: http://urss.knuba.edu. ua / zbirnyk-7 / article-240.

4. Blank, I. (2006). Financial strategy of the enterprise. K.: Elga: Nika centre, 456.

5. Bushuyeva, N. (2010). Management of development of the enterprises of building branch by formation of their strategic potential: author's ref. dis. for science. degree of Cand. tech. science: special. 05.13.22 - project management and production development. Kyiv National University of Construction and Architecture. Kyiv, 20 p. 
6. Yegorchenkova, N. (2012). Integration of matrix technologies and method of critical chains and resource management of portfolios of projects and programs [Text]: coll. Science. etc. Management of complex systems development, no. 7, 30-35.

7. Chupryna, K. (2019). Modeling of spatial data on the construction site based on multidimensional information objects. International Journal of Engineering and Advanced Technology, vol. 8, no. 6, 39343940

8. Chupryna, Y. (2018). The organization of biosphere compatibility construction: Justification of the predictors of building development and the implementation prospects. International Journal of Engineering and Technology (UAE), vol. 7, no. 3, 545-549.

9. Ushatsky, S. (2008). Innovative conceptual and formal-analytical tools for substantiation, preparation and implementation of construction investment projects. A monograph. Kyiv, 208. 